\title{
IMPLIKASI PENGUNGKAPAN BEBAN CORPORATE SOCIAL RESPONSIBILITY PADA KINERJA PASAR PERUSAHAAN YANG TERDAFTAR DI BEI
}

\author{
Ni Wayan Septia Wini ${ }^{1}$ \\ Made Gede Wirakusuma ${ }^{2}$ \\ Maria M. Ratnasari ${ }^{3}$ \\ ${ }^{1,2,3}$ Fakultas Ekonomi dan Bisnis Universitas Udayana, Bali, Indonesia \\ email: septiawini@gmail.com
}

\begin{abstract}
ABSTRAK
Tujuan penelitian adalah untuk memperoleh bukti empiris pengaruh pengungkapan beban CSR pada kinerja pasar perusahaan yang terdaftar di BEI dan menguji perbedaan kinerja pasar perusahaan keuangan dan non keuangan yang mengungkapkan beban CSR di BEI. Populasi dalam penelitian ini adalah perusahaan keuangan dan non keuangan yang terdaftar di BEI tahun 2011-2015. Metode sampling yang digunakan adalah metode purposive sampling. Sampel terdiri dari 11 perusahaan keuangan dan 18 perusahaan non keuangan. Teknik analisis menggunakan uji regresi linear sederhana dan independent sample t-Test. Hasil pengujian menunjukkan terdapat pengaruh negatif signifikan antara pengungkapan beban CSR dengan kinerja pasar perusahaan yang terdaftar di BEI. Diketahui juga bahwa tidak terdapat perbedaan kinerja pasar perusahaan keuangan dan non keuangan yang mengungkapkan beban CSR.
\end{abstract}

Kata kunci: Pengungkapan Beban CSR, Kinerja Pasar Perusahaan, Perusahaan Keuangan, Perusahaan Non Keuangan

\begin{abstract}
The purpose of this study was to obtain empirical evidence of the influence of CSR disclosure of expenses on the market performance of companies listed on the BEI and examine the differences in market performance of financial and non-financial companies that revealed the expenses of CSR in BEI. The population in this study are the financial and non financial companies listed on the Stock Exchange in 2011-2015. The sampling method that used is purposive sampling method. The samples consisted of 11 financial companies and 18 non-financial companies. Analysis technique used is simple linear regression test and independent sample t-Test. The test results show there is a significant negative influence between the disclosure of CSR expenses with market performance of the companies listed on the BEI. Also found that there are differences in the performance of financial markets and non-financial companies that disclose their CSR expense
\end{abstract}

Keywords: The Disclosure of CSR Expenses, Market Performance, Financial Companies, Non-Financial Companies. 


\section{PENDAHULUAN}

Teori signalling menyatakan bahwa suatu informasi dapat dimanfaatkan oleh perusahaan untuk memberikan sinyal kepada pihak yang berkepentingan. Salah satu media penyampaian informasi yang biasanya digunakan oleh perusahaan adalah dalam laporan tahunan. Informasi ini bagi investor maupun calon investor merupakan suatu kebutuhan yang mendasar karena dengan adanya informasi yang informatif memungkinkan para investor untuk melakukan pengambilan keputusan (Nurdin dan Cahyandito, 2006).

Akuntansi konvensional yang selama ini berkembang diketahui bahwa pelaporan akuntansi oleh perusahaan lebih banyak digunakan sebagai media pertanggung jawaban kepada stockholders dan bondholders. Orientasi perusahaanpun cenderung lebih mengarah pada laba material, mengakibatkan perusahaan melakukan pemborosan dalam penggunaan sumber alam dan masyarakat (sosial) sehingga berdampak pada keadaan lingkungan (Anggraini, 2006). Hal tersebut mengakibatkan akuntansi konvensional sekarang ini sudah mulai dikritik dikarenakan tidak mampu lagi mengakomodir kepentingan masyarakat secara luas. Hal ini memicu munculnya suatu konsep akuntansi untuk mengatasi masalah tersebut yaitu akuntansi pertanggung jawaban sosial atau akuntansi sosial. Hendarti (2006) mengungkapkan dewasa ini telah terjadi perubahan paradigma dimana pertanggungjawaban hasil akuntansi tidak lagi hanya diarahkan pada pemlik saham tetapi juga ditujukan kepada semua stakeholders. 
McGuire et al. (1988) berpendapat bahwa pihak yang berkepentingan lebih peduli pada tanggung jawab sosial serta pengungkapan beban sosial terutama dalam keputusan ekonominya. Investor yang tertarik pada isu tanggung jawab sosial ini berkaitan dengan pemilihan investasi, dimana investor lebih memilih investasi yang menguntungkan. Anggraini (2006) mengungkapkan pengambilan keputusan dengan hanya melihat pada aspek laba suatu perusahaan dirasa kurang relevan lagi oleh para investor. Investor lebih tertarik mengenai informasi tanggung jawab sosial perusahaan atau corporate social responsibility (CSR) yang dilaporkan dalam laporan tahunan.

CSR dalam World Business Council for Sustainable Development (WBCSD) (1999) adalah kewajiban yang berkesinambungan di dunia usaha dan berperan pada peningkatan ekonomi serta meningkatkan kualitas hidup tenaga kerja beserta masyarakat pada umumnya. Single bottom line dimana nilai perusahaan yang hanya digambarkan dengan kondisi keuangan semata, tidaklah menjadi satu-satunya pegangan dalam CSR. Munculnya triple bottom lines yang meliputi aspek keuangan, sosial dan lingkungan sekarang ini menjadi pegangan utama dalam CSR. Peraturan mengenai CSR di Indonesia sudah tertuang dalam Undang-Undang No.40 Tahun 2007 tentang Perseroan Terbatas pasal 74 ayat 1 isinya menjelaskan bahwa perusahaan yang menjalankan kegiatan usahanya di bidang dan atau berkaitan dengan sumber daya alam wajib melaksanakan tanggung jawab sosial dan lingkungan.

Umumnya perusahaan memaparkan aktivitas CSR-nya dalam laporan tahunan perusahaan atau laporan khusus CSR. Global Reporting Intiative (GRI) 
memfokuskan tiga indikator pengungkapan CSR, yaitu: indikator ekonomi terdiri dari sembilan item, indikator lingkungan terdiri dari 30 item dan indikator sosial terdiri dari 40 item yang meliputi aspek tenaga kerja, hak asasi manusia sosial dan tanggung jawab produk (Vijaya, 2012). Selain itu Yamagami dan Kokobu (1991) juga mengatakan bahwa pengungkapan tanggung jawab sosial perusahaan dapat dilakukan berupa beban sosial yang dikelompokkan berdasarkan 1) lingkungan, 2) lingkungan masyarakat, 3) kepegawaian, 4) penelitian dan pengembangan dan 5) aktivitas international. Informasi CSR yang dilaporkan perusahaan dalam laporan tahunan nantinya diharapkan mampu memberikan sinyal kepada investor. Informasi akan bernilai tambah bagi investor jika informasi tersebut direspon oleh investor di pasar modal.

Penelitian dengan menggunakan topik CSR telah banyak dilakukan baik di dalam maupun di luar negeri. Berikut beberapa hasil penelitian tentang CSR di luar negeri, Hall dan Rieck (1998) menggunakan sampel perusahaan yang melakukan kegiatan sosial (CSR) periode 1982-1995 di Wall Street Journal. Bukti pertama mengatakan bahwa kegiatan CSR memiliki dampak positif pada kinerja pasar perusahaan. Hasil kedua diketahui bahwa pasar membuat keputusan secara berbeda pada berbagai jenis pengungkapan CSR. Wang (2011) dalam penelitiannya menemukan bukti bahwa dengan dimilikinya tanggung jawab sosial yang tinggi oleh perusahaan akan mengakibakan kinerja pasar saham yang baik, terbalik dengan perusahaan yang kurang memiliki memiliki tanggung jawab sosial. Selanjutnya dikatakan juga bahwa perusahaan yang bertanggung jawab 
kepada lingkungan sosial disekitarnya akan mendapatkan citra perusahaan yang baik dimata investor, sehingga akan berimbas pada kinerja saham yang lebih baik.

Di Indonesia sendiri penelitian mengenai CSR memberikan hasil yang cukup beragam, seperti studi oleh Ilmi, dkk. (2015) mengungkapkan bahwa program CSR yang dilakukan perusahaan pertambangan berpengaruh pada keputusan investasi investor di pasar modal dengan nilai signifikansi sebesar 0,001. Sejalan dengan penelitian Budiman dan Juniarti (2015) juga membuktikan CSR berpengaruh positif terhadap abnormal return perusahaan sektor perdagangan, jasa dan investasi. Selain itu terdapat juga hasil penelitian yang tidak konsisten dengan penelitian tersebut yaitu Oktavia dan Juniarti (2015) dimana dibuktikan bahwa CSR tidak berpengaruh terhadap comulative abnormal return (CAR). Berikutnya ada Titisari, dkk (2010) membuktikan bahwa CSR tidak berpengaruh pada stock return yang diproksi dengan CAR. Menandakan bahwa investor kurang memberikan perhatian pada kegiatan sosial perusahaan dalam melakukan keputusan investasi.

Beberapa penelitian di Indonesia yang diungkapkan sebelumnya masih memberikan hasil yang beragam maka dari itu peneliti ingin melakukan pengujian kembali. Peneliti ingin kembali melanjutkan penelitian mengenai tema yang serupa tetapi tidak menggunakan GRI atau CSRI sebagai pengungkapan CSR melainkan menggunakan pengungkapan beban CSR yang diungkapkan oleh perusahaan. Penelitian ini akan mengaitkan pengaruh antara pengungkapan beban CSR dengan kinerja pasar perusahaan yang diukur menggunakan cumulative abnormal return. Perusahaan yang digunakan tidak hanya perusahaan yang 
berkenaan dengan sumber daya alam melainkan semua perusahaan yang terdaftar di Bursa Efek Indonesia (BEI) termasuk sektor keuangan periode 2011-2015 dengan total jumlah perusahaan 432. Jumlah perusahaan keuangan yang terdaftar beturut-turut selama periode 2011-2015 sejumlah 65 dan untuk perusahaan non keuangan berjumlah 367 perusahaan.

Berdasarkan ulasan tersebut maka rumusan permasalahannya adalah bagaimana pengaruh pengungkapan beban CSR pada kinerja pasar perusaaan yang terdaftar di BEI? serta bagaimana perbedaan kinerja pasar perusahaan keuangan dan non keuangan yang mengungkapkan beban CSR di BEI. Mendapatkan bukti secara empiris pengaruh pengungkapan beban CSR pada kinerja pasar perusaaan yang terdaftar di BEI serta menguji perbedaan kinerja pasar perusahaan keuangan dan non keuangan yang mengungkapkan beban CSR di BEI merupakan tujuan dari penelitian ini.

Manfaat teoretis dan manfaat praktis diharapkan didapat dari hasil penelitian ini. Aspek teoritis penelitian ini memiliki tujuan untuk dapat menambah pengetahuan dalam pengembangan teori signalling. Teori signalling menjelaskan bahwa perusahaan memanfaatkan informasi yang dimiliki untuk memberikan sinyal kepada investor ataupun calon investor. Baik itu sinyal baik ataupun buruk dengan harapan investor dan calon investor akan bereaksi ketika informasi tersebut diumumkan. Manfaat praktis dari penelitian ini diharapkan untuk dapat memberikan sumbangan pemikiran bagi para investor mengenai informasi apa saja yang diungkapkan oleh perusahaan. Informasi tersebut nantinya diharapkan dapat menjadi suatu bahan pertimbangan dalam pengambilan keputusan. Bagi 
perusahaan penelitian ini nantinya dapat memberikan gambaran bahwa informasi yang diungkapkan oleh perusahaan direspon oleh investor dan berdampak terhadap kinerja perusahaan.

Ketersediaan informasi merupakan hal yang erat hubungannya dengan teori signalling. Informasi adalah komponen yang substansial bagi investor, dikarenakan informasi mampu memberikan eksplanasi, potret mengenai kondisi masa lalu, saat ini dan masa datang bagi kelangsungan hidup perusahaan. Informasi yang diungkapkan sebagai suatu pengumuman akan menyampaikan sinyal baik atau sinyal buruk bagi investor dan apabila informasi tersebut bermanfaat maka investor diharapkan akan bereaksi saat pengumuman tersebut diterima investor di pasar modal (Jogiyanto, 2000).

Pada umumnya informasi akuntansi yang selama ini diungkapkan oleh perusahaan menggunakan akuntansi konvesional yang secara kuantitatif belum melakukan pengungkapan social benefit dan social cost yang ditimbulkan oleh aktivitas perusahaan. Sehingga diperlukan suatu metode baru yang dapat menata, mengukur dan mengungkapkan dampak pertukaran antara perusahaan dan lingkungan masyarakat disekitar, yang disebut sebagai akuntansi ekonomi kemasyarakatan atau akuntansi pertanggungjawaban sosial. Luhgiatno (2007) berpandangan bahwa fokus akuntansi sosial lebih pada menyajikan gambaran komprehensif aktivitas dan hubungan organisasi terhadap lingkungan eksternalnya. Hal ini akan mampu memerikan informasi mengenai sejauh mana organisasi memiliki peran baik positif atau negatif pada kualitas hidup makhluk hidup dan lingkungannya. 
Parker et al. (1989) dalam Murni (2001) membagi beberapa kategori model alternatif pelaporan keuangan yang berhubungan dengan dampak sosial sebagai akibat dari aktivitas perusahaan. Perusahaanpun dapat memilih salah satu model pelaporan tersebut yakni; inventory approach, outlay cost approach, cost benefit approach, program management approach dan goal accounting approach.

Hohnen (2007) menyebutkan jajak pendapat bisnis dan perilaku perusahaan yang telah dilakukan, menunjukkan peningkatan tingkat pemahaman tentang hubungan antara bisnis yang bertanggung jawab dan bisnis yang baik. Selain itu investor dan pasar keuangan kini semakin melirik kegiatan CSR yang mengintegrasikan keprihatinan sosial yang lebih luas ke dalam strategi bisnis dan kinerja perusahaan. Selain dapat membangun kepercayaan masyarakat, keunggulan dalam menarik pelanggan, bertanggung jawab terhadap pekerja dan orang lain dalam masyarakat, CSR dapat membantu membangun nilai perusahaan dan pemegang saham perusahaan.

Menurut International Organization for Standardization (ISO) 26000 (2010), CSR adalah dimana sebuah organisai mampu memberikan tanggung jawab sosialnya terhadap dampak dari semua keputusan serta kegiatan yang dilakukan pada masyarakat dan lingkungan dengan dilakukan dalam bentuk tindakan etis dan trasparan yang berdampingan dengan pembangungan berkelanjutan dan kesejahteraan masyarakat. ISO 26000 (2010) menyatakan ketika suatu perusahaan atau organisasi akan mulai melakukan dan berlatih tanggung jawab sosial, tujuan yang ingin dicapai adalah untuk memaksimalkan kontribusinya terhadap pembangunan berkelanjutan. Dalam tujuan ini, organisasi 
atau perusahaan harus menghormati beberapa prinsip CSR yaitu; akuntabilitas, transparansi, perilaku etis, menghormati aturan hukum, norma-norma dan hak asasi manusia.

Undang-Undang No.40 Tahun 2007 tentang Perseroan Terbatas pasal 66 ayat 2 mengungkapkan bahwa laporan tahunan perseroan harus memuat sekurangkurangnya salah satunya adalah laporan pelaksanaan Tanggung Jawab Sosial dan Lingkungan. Terdapat pula peraturan Menteri Negara BUMN No. PER05/MBU/2007 tanggal 27 April 2007, dimana perusahaan BUMN wajib menyisihkan dana untuk program kemitraan sebesar 2\% dari keuntungan bersih perusahaan dan 2\% pula untuk Program Bina Lingkungan. Kegiatan tanggung jawab sosial perusahaan tersebut diungkapkan dalam laporan yang disebut sustainability reporting. Pengugkapan tersebut juga dilakukan di dalam laporan tahunan perusahaan (annual report). Sueb (2001) menyebutkan sarana penyajian tanggung jawab sosial perusahaan khususnya pada perusahaan terbuka menggunakan media yang beragam. Media yang paling dominan digunakan adalah; penyajian biaya pengelolaan lingkungan pada prosepektus; biaya kesejahteraan pegawai pada catatan atas laporan keuangan; biaya masyarakat sekitar perusahaan pada laporan tahunan; biaya pemantauan produk pada catatan atas laporan keuangan.

Bagi perusahaan yang terlibat dalam beberapa aspek sosial, baik di dalam perusahaan dan di luar, akan berdampak pada produk dan jasa perusahaan menjadi lebih menarik bagi konsumen secara keseluruhan, hal ini membuat perusahaan menjadi lebih diuntungkan. Akan ada peningkatan beban untuk melaksanakan 
CSR, tetapi manfaat yang mungkin jauh lebih besar daripada beban yang dikeluarkan. Berdasarkan studi yang dilakukan WBSCD, telah menarik beberapa kesimpulan tentang manfaat CSR untuk perusahaan (Hohnen, 2007:14):

a) Strategi CSR yang koheren, berdasarkan integritas, nilai-nilai moral dan pendekatan jangka panjang, menawarkan manfaat bisnis yang jelas untuk perusahaan dan membantu suatu perusahaan memberikan kontribusi positif kepada masyarakat;

b) Strategi CSR menyediakan bisnis dengan kesempatan untuk menunjukkan rasa kemanusiaan perusahaan;

c) Strategi seperti ini membutuhkan keterlibatan dalam dialog terbuka dan kemitraan yang konstruktif dengan pemerintah di berbagai tingkatan, organisasi antar pemerintah, organisasi non-pemerintah, elemen masyarakat sipil lainnya dan, khususnya, masyarakat lokal;

d) Ketika menerapkan strategi CSR, perusahaan harus mengakui dan menghormati perbedaan lokal dan budaya, sambil mempertahankan standar global yang tinggi dan konsisten dan kebijakan; dan

e) Menjadi responsif terhadap perbedaan lokal yang berarti mengambil inisiatif spesifik.

Informasi CSR yang dilaporkan perusahaan diharapkan mampu memberikan sinyal kepada investor. Apabila terjadi kenaikan pembelian saham dan berakibat terjadi peningkatan harga saham yang melebihi return ekspektasian investor, maka informasi tersebut direspon oleh investor di pasar modal. Abnormal return merupakan salah satu indikator yang dapat digunakan untuk 
menilai kinerja pasar perusahaan. Return normal merupakan return ekspektasian dari investor (return yang memang diharapkan oleh investor), sedangkan abnormal return adalah selisih antara return sesungguhnya dengan return ekspektasian. Abnormal return menjadi positif jika return yang diperoleh lebih tinggi dari return ekspektasian. Sedangkan abnormal return menjadi negatif jika return yang diperoleh lebih rendah dari return ekspektasian (Kastutisari dan Dewi, 2014).

Akanbi et al. (2012) mengungkapkan dimensi CSR memiliki pengaruh pada kinerja perusahaan perbankan di Nigeria. Berikutnya ada Sukanto (2015) menggunakan perusahaan yang berkaitan dengan lingkungan di BEI dimana membuktikan bahwa pengungkan CSR lingkungan, ekonomi dan sosial berpengaruh pada keputusan investor untuk melakukan investasi di pasar saham. Ilmi, dkk. (2015) yang melakukan studi perusahaan pertambangan tahun 20112013 juga mendapatkan hasil positif dimana program CSR memberikan pengaruh pada keputusan investasi pada perusahaan pertambangan di BEI. Mwamburi (2015) menggunakan delapan sektor perusahaan di Nairobi Securities Exchange mengungkapkan CSR mempunyai dampak yang berguna pada stock returns yang diukur menggunakan CAR. Pengungkapan beban CSR diharapkan mengandung kandungan informasi, sehingga pasar atau investor akan bereaksi setelah pengumuman itu diterima. Hipotesis yang diajukan adalah:

$\mathrm{H}_{1 \mathrm{a}}$ : Pengungkapan beban CSR berpengaruh positif signifikan pada kinerja pasar perusahaan yang terdaftar di Bursa Efek Indonesia

$\mathrm{H}_{1 \mathrm{~b}}$ : Pengungkapan beban CSR berpengaruh positif signifikan pada kinerja pasar perusahaan keuangan yang terdaftar di Bursa Efek Indonesia 
$\mathrm{H}_{1 \mathrm{c}}$ : Pengungkapan beban CSR berpengaruh positif signifikan pada kinerja pasar perusahaan non keuangan yang terdaftar di Bursa Efek Indonesia

Penelitian Putranto dan Kewal (2014) yang menguji pengaruh CSR berbasis karakteristik social bank terhadap kinerja perusahaan perbankan menemukan hasil bahwa CSR tidak mempengaruhi peningkatan kinerja perusahaan perbankan yang diukur menggunakan Tobin's $Q$. Kontras dengan penelitian yang dilakukan oleh Budiman dan Juniarti (2015) ditemukan bahwa pengungkapan CSR pada sektor perdagangan, jasa dan investasi mempengaruhi respon investor di pasar saham yang diukur dengan menggunakan CAR. Mawandira, dkk. (2014) menemukan bukti bahwa sektor industri non keuangan dan non BUMN yang terdaftar di BEI 2010-2012 memiliki pengungkapan CSR yang berbeda untuk tiap sektor maupun tiap tahunnya.

$\mathrm{H}_{2}$ : Terdapat perbedaan kinerja pasar perusahaan keuangan dan non keuangan yang mengungkapkan beban CSR di Bursa Efek Indonesia.

\section{METODE PENELITIAN}

Lokasi penelitian dilakukan di BEI. Penelitian ini menggunakan data sekunder perusahaan keuangan dan non keuangan yang mengungkapkan beban CSR melalui situs www.idx.go.ig, finance.yahoo.com serta duniainvestasi.com Waktu penelitian ini menggunakan periode dari tahun 2011 sampai dengan 2015.

Variablel yang diteliti pada penelitian ini adalah kinerja pasar perusahaan dan pengungkapan beban CSR berdasarkan teori dan hipotesis yang telah dijelaskan. Kinerja pasar perusahaan merupakan variabel dependen yang dimana nantinya akan dipengaruhi oleh variabel independen yaitu pengungkapan beban 
CSR. Kinerja pasar dalam penelitian ini akan dihitung dengan menggunakan abnormal return. Abnormal return ditunjukkan oleh selisih antara return realisasi dengan return ekspektasi (expected return). Return ekspektasi akan dihitung menggunakan market adjusted model.

Variabel pengungkapan beban CSR dihitung menggunakan alokasi beban CSR, dimana beban CSR yang digunakan adalah beban pengelolaan lingkungan merupakan beban yang dikeluarkan perusahaan yang terkait akan pelestarian lingkungan hidup dan menjaga kualitas dari setiap komponen lingkungan hidup. Beban kesejahteraan karyawan adalah beban yang dikeluarkan oleh perusahaan untuk memberikan kompensasi atas hasil kerja pegawai selama berkerja. Beban untuk masyarakat sekitar atau komunitas merupakan beban yang digunakan oleh perusahaan untuk masyarakat atau komunitas yang berada disekitar perusahaan. Beban pemantauan produk merupakan beban yang dikeluarkan oleh perusahaan untuk melakukan pemantauan pada produknya berkaitan dengan kualitas serta kepuasan konsumen.

Populasi penelitian ini adalah perusahaan keuangan dan non keuangan yang terdaftar di BEI periode 2011-2015. Teknik non probabilitas sampling digunakan untuk menentukan sampel yakni metode purposive sampling. Analisis regresi linear sederhana digunakan menguji pengaruh pengungkapan beban CSR pada kinerja pasar adalah analisis regresi linear sederhana. Berikutnya digunakan juga Independent Sample t-Test untuk menguji apakah terdapat perbedaan kinerja pasar perusahaan keuangan dan non keuangan yang mengungkapkan beban CSR. 


\section{HASIL DAN PEMBAHASAN}

Hasil dari pemilahan sampel penelitian menunjukkan bahwa jumlah sampel yang akan digunakan dalam adalah sebanyak 29 perusahaan terdiri dari 11 perusahaan keuangan dan 19 perusahaan non keuangan. Berikut akan diberikan hasil dari statistik deskriptif pada tabel 1, statistik dekriptif ini berfungsi untuk menginformasikan tentang karakteristik variabel-variabel penelitian, seperti nilai minimum, maksimum, mean (rata-rata) dan standar deviasi.

\section{Tabel 1}

\section{Statistil Deskriptif}

\begin{tabular}{lrrrrr}
\hline \multicolumn{1}{c}{ Variabel } & N & Minimum & Maximum & \multicolumn{1}{c}{ Mean } & $\begin{array}{c}\text { Std. } \\
\text { Deviation }\end{array}$ \\
\hline ABCSR $\left(\mathrm{X}_{1}\right)$ & 139 & $-2,322$ & 1,334 & 0,251 & 0,337 \\
CAR (Y) & 139 & $-0,556$ & 0,417 & $-0,066$ & 0,105 \\
\hline Sumber: Data diolah, 2016 & & & &
\end{tabular}

Tabel 1 menunjukkan jumlah data adalah 139, jumlah ini sudah dikurangi dengan data outlier yang berjumlah 6 data. Hal ini mengakibatkan jumlah data yang awalnya 145 berubah menjadi 139 data penelitian. Nilai variabel pengungkapan beban CSR $\left(\mathrm{X}_{1}\right)$ yang diukur dengan alokasi biaya CSR (ABCSR) memiliki nilai terendah yaitu $-2,322$ persen yang terdapat pada perusahaan ANTM dan yang tertinggi sebesar 1,334 persen dimiliki oleh DGIK. Hasil tabel juga menunjukkan besarnya nilai rata-rata perubahan positif yaitu sebesar 0,251 dan besarnya standar deviasi adalah 0,337 . Kondisi tersebut menunjukkan bahwa ratarata besarnya alokasi beban CSR perusahaan di BEI adalah sebesar 0,251 persen dari laba bersih. Hal ini menandakan adanya peningkatan rata-rata sebesar 0,251 persen selama tahun amatan dilihat dari nilai rata-rata yang mendekati nilai maksimum. 
Kinerja pasar perusahaan (Y) yang diukur dengan CAR memiliki nilai terendah yaitu $-0,556$ atau $-55,6$ persen pada perusahaan PTBA. Nilai tertinggi terdapat pada ANTM sebesar 0,417 atau 41,7 persen. Rata-rata CAR adalah negatif yaitu $-0,066$ dan besarnya standar deviasi adalah 0,105 . Ini menandakan setiap tahunnya selama periode amatan terjadi penurunan rata-rata CAR perusahaan di BEI sebesar $-6,6$ persen, dilihat dari nilai rata-rata yang mendekati nilai minimum.

Model regresi yang baik adalah berdistribusi normal. Hasil uji normalitas untuk hipotesis $\mathrm{H}_{1 \mathrm{a}}$ adalah 4,709 dengan nilai Asymp. Sig. (2-tailed) sebesar 0,000 ini menunjukkan jika nilai 0,000 lebih kecil dari $\alpha=5 \%$ atau 0,05 . Hasil ini menandakan bahwa data residual tidak berdistribusi normal. Hal yang dilakukan untuk mengatasi data tidak berdistribusi normal adalah dengan mengeluarkan data outlier Setelah melakukan pengujian data outlier diketahui terdapat 6 data outlier dalam penelitian ini, Keenam data outlier tersebut akhirnya dikeluarkan dari sampel penelitian sehingga jumlah data penelitian yang awalnya 145 berkurang menjadi 139 data penelitian. Setelah data outlier dikeluarkan maka dilakukan kembali uji normalitas, hasil uji kolmogorov-smirnov menunjukkan nilai 0,992 dan nilai Asymp. Sig. (2-tailed) sebesar 0,278. Menandakan nilai 0,278 lebih besar dari $\alpha=0,05$, dikatakan data residual berdistribusi normal. Hasil uji untuk hipotesis $\mathrm{H}_{1 \mathrm{~b}}$ adalah 1,329 dengan Asymp. Sig. (2-tailed) sebesar 0,059, ini menunjukkan bahwa nilai 0,059 lebih besar dari $\alpha=0,05$, ini berarti data residual berdistribusi normal. Sementara untuk hipotesis $\mathrm{H}_{1 \mathrm{c}}$ nilai Asymp. Sig. (2-tailed) sebesar 0,000 lebih kecil dari $\alpha=0,05$, untuk mengatasi hal ini dilakukan juga 
pengeluaran data outlier. Selanjutnya dilakukan kembali pengujian normalitas sehingga hasil kolmogorov- smirnov Sig. (2-tailed) menjadi sebesar 0,542, ini menyatakan data residual juga berdistribusi normal.

Hasil pengujian heteroskedastisitas hipotesis $\mathrm{H}_{1 \mathrm{a}}$ menunjukkan nilai probabilitas signifikansi variabel bebas lebih dari 0,05 yaitu sebesar 0,134. Disimpulkan bahwa model regresii bebas dari heteroskedastisitas. Hasil pengujian heteroskedastisitas untuk hipotesis $\mathrm{H}_{1 \mathrm{~b}}$ dan $\mathrm{H}_{1 \mathrm{c}}$ juga menunjukkan nilai probabilitas signifikansi variabel bebas lebih dari 0,05 yaitu secara berturut-turut sebesar 0,522 dan 0,320. Maka dikatakan bahwa kedua model regresi bebas dari heteroskedastisitas.

Uji autokorelasi untuk hipotesis $\mathrm{H}_{1 \mathrm{a}}$ menunjukkan model regresi yang digunakan di penelitian ini tidak terdapat autokorelasi positif atau negatif, dimana dilihat dari nilai DW yang sebesar 1,968 sehingga $1,737<1,968<$ (41,968=2,032). Nilai dari DW untuk hipotesis $\mathrm{H}_{1 \mathrm{~b}}$ sebesar 1,978 sehingga $1,601<$ $1,978<(4-1,978=2,022)$, pada hipotesis $\mathrm{H}_{1 \mathrm{c}}$ menunjukkan $1,674<1,982<(4-$ $1,982=2,018)$ maka disimpulkan tidak terdapat autokorelasi positif atau negatif pada kedua model regresi

Hipotesis $\mathrm{H}_{1 \mathrm{a}}$ menyatakan pengungkapan beban CSR berpengaruh positif signifikan pada kinerja pasar perusahaan di BEI. Pengujian terhadap hipotesis ini menggunakan uji analisis regresi linear sederhana. Hasil uji hipotesis $\mathrm{H}_{1 \mathrm{a}}$ dapat dilihat pada Tabel 2 . 


\section{Tabel 2}

\section{Hasil Uji Regresi Linear Sederhana Hipotesis $\mathbf{H}_{1 a}$}

\begin{tabular}{lrcc}
\hline & $\begin{array}{c}\text { Unstandardized } \\
\text { coefficients } \\
\beta\end{array}$ & $\mathrm{t}$ & Sig. \\
\hline (Constant) & 0,015 & 1.398 & 0,164 \\
ABCSR & $-0,086$ & $-3,364$ & 0,001 \\
$R$ Square $\left(\mathrm{R}^{2}\right)$ & & 0,076 & \\
\hline
\end{tabular}

Sumber: Data diolah, 2016

Besarnya nilai $\mathrm{R}^{2}$ adalah 0,076 . Hal tersebut menunjukkan bahwa variabilitas kinerja pasar perusahaan di BEI dapat dijelaskan oleh pengungkapan beban CSR sebesar 7,6 persen, dan sisanya sebesar 93,4 persen dijelaskan variabel-variabel lain di luar model penelitian. Diketahui nilai koefisien konstanta sebesar 0,015 menunjukkan jika nilai variabel ABCSR sebesar nol, maka nilai dari CAR sebesar 0,015. Nilai koefisien regresi ABCSR sebesar -0,086 menunjukkan bahwa jika nilai pengungkapan beban CSR (ABCSR) naik 1 persen maka kinerja pasar (CAR) turun sebesar 8,6 persen. Pada Tabel 2 dapat dilihat beta unstandardized ABCSR bernilai negatif sebesar -0,086 dengan nilai signifikansi 0,001 lebih kecil dari $\alpha=0,05$. Ini berarti bahwa pengungkapan beban CSR memiliki pengaruh negatif signifikan pada kinerja pasar perusahaan yang terdaftar di Bursa Efek Indonesia.

Hipotesis $\mathrm{H}_{1 \mathrm{~b}}$ menyatakan pengungkapan beban CSR berpengaruh positif signifikan pada kinerja pasar perusahaan keuangan di BEI. Hasil uji hipotesis $\mathrm{H}_{1 \mathrm{~b}}$ dapat dilihat pada Tabel 3. 


\section{Tabel 3}

\section{Hasil Uji Regresi Linear Sederhana Hipotesis $\mathbf{H}_{1 b}$}

\begin{tabular}{lccc}
\hline & $\begin{array}{c}\text { Unstandardized } \\
\text { coefficients } \\
\end{array}$ & $\mathrm{t}$ & Sig. \\
\hline (Constant) & 0,009 & 0,640 & 0,525 \\
$\mathrm{ABCSR}$ & 0,003 & 0,460 & 0,648 \\
$R$ Square $\left(\mathrm{R}^{2}\right)$ & & 0,004 & \\
\hline
\end{tabular}

Sumber: Data diolah, 2016

Nilai $\mathrm{R}^{2}$ mengalami penurunan dengan nilai 0,004 . Hal tersebut menunjukkan bahwa variabilitas kinerja pasar perusahaan keuangan di BEI dapat dijelaskan oleh pengungkapan beban CSR sebesar 0,4 persen, dan sisanya sebesar 99,6 persen dijelaskan oleh variabel-variabel lain di luar model penelitian. Tabel 2 menjelaskan bahwa nilai koefisien konstanta sebesar 0,009 menunjukkan jika nilai variabel ABCSR sebesar nol, maka nilai dari CAR sebesar 0,009. Nilai koefisien regresi ABCSR sebesar 0,003 menunjukkan bahwa jika nilai pengungkapan beban CSR (ABCSR) naik 1 persen maka kinerja pasar (CAR) naik sebesar 0,3 persen. Nilai beta unstandardized ABCSR adalah positif sebesar 0,003 dan nilai signifikansi 0,648 lebih besar dari $\alpha=0,05$. Ini berarti bahwa $\mathrm{H}_{1 \mathrm{~b}}$ ditolak dimana pengungkapan beban CSR tidak berpengaruh pada kinerja pasar perusahaan keuangan yang terdaftar di Bursa Efek Indonesia.

Selanjutnya hipotesis $\mathrm{H}_{1 \mathrm{c}}$ dimana dikatakan pengungkapan beban CSR berpengaruh positif signifikan pada kinerja pasar perusahaan non keuangan di BEI. Hasil uji hipotesis $\mathrm{H}_{1 \mathrm{c}}$ dapat dilihat pada Tabel 4. 


\section{Tabel 4}

\section{Hasil Uji Regresi Linear Sederhana Hipotesis $\mathbf{H}_{1 \mathrm{c}}$}

\begin{tabular}{lccc}
\hline & $\begin{array}{c}\text { Unstandardized } \\
\text { coefficients } \\
\beta\end{array}$ & $\mathrm{t}$ & Sig. \\
\hline (Constant) & 0,001 & 0,096 & 0,924 \\
ABCSR & $-0,045$ & $-2,016$ & 0,047 \\
$R$ Square $\left(\mathrm{R}^{2}\right)$ & & 0,046 & \\
\hline
\end{tabular}

Sumber: Data diolah, 2016

Menurut Tabel 4 dapat dijelaskan bahwa nilai koefisien konstanta sebesar 0,001 menunjukkan jika nilai variabel ABCSR sebesar nol, maka nilai dari CAR sebesar 0,001. Nilai koefisien regresi ABCSR sebesar -0,045 menunjukkan bahwa jika nilai pengungkapan beban CSR (ABCSR) naik 1 persen maka kinerja pasar (CAR) turun sebesar 4,5 persen. Nilai dari $\mathrm{R}^{2}$ adalah sebesar 0,046 , berarti variabilitas kinerja pasar perusahaan non keuangan dapat dijelaskan oleh pengungkapan beban CSR sebesar 4,6 persen, dan sisanya sebesar 95,4 persen dijelaskan oleh variabel-variabel lain di luar model penelitian. Terlihat bahwa beta unstandardized ABCSR bernilai negatif sebesar $-0,045$ dengan nilai signifikansi 0,047 lebih kecil dari $\alpha=0,05$. Ini berarti bahwa $\mathrm{H}_{1 \mathrm{c}}$ ditolak dimana pengungkapan beban CSR berpengaruh negatif signifikan pada kinerja pasar perusahaan non keuangan yang terdaftar di Bursa Efek Indonesia.

Hipotesis kedua menyatakan terdapat perbedaan kinerja pasar perusahaan keuangan dan non keuangan yang mengungkapkan beban CSR. Pengujian hipotesis menggunakan Independent sample t-Test. Hasil pengujian dapat dilihat pada Tabel 5. 
Tabel 5

Hasil Uji Beda Parametrik Independent Sample t-Test

\begin{tabular}{|c|c|c|c|c|c|c|}
\hline & & \multicolumn{2}{|c|}{$\begin{array}{l}\text { Levene's Test for } \\
\text { Equality of Variance }\end{array}$} & \multicolumn{2}{|c|}{ t-test for Equality of Means } & \multirow[b]{2}{*}{$\begin{array}{l}\text { Sig. }(2- \\
\text { tailed) }\end{array}$} \\
\hline & & $\mathrm{F}$ & Sig. & $\mathrm{t}$ & $\mathrm{df}$ & \\
\hline \multirow[b]{2}{*}{$\begin{array}{c}\text { Kinerja } \\
\text { Pasar }\end{array}$} & $\begin{array}{c}\text { Equal } \\
\text { variances } \\
\text { assumed }\end{array}$ & 2.334 & 0,129 & 1,046 & 140 & 0,297 \\
\hline & $\begin{array}{c}\text { Equal } \\
\text { variances } \\
\text { not } \\
\text { assumed }\end{array}$ & & & 1,081 & 126,841 & 0,282 \\
\hline
\end{tabular}

Sumber: Data diolah, 2016

Sebelum menentukan apakah terdapat perbedaan rata-rata atau tidak, terlebih dahulu yang dilakukan adalah menentukan apakah variance data penelitian homogen atau tidak. Hal ini dapat dilihat pada kolom Levene's Test, dimana nilai Sig. 0,129 lebih besar dari $\alpha$ sebesar 0,05. Dikatakan variance data penelitian homogen, karena homogen kolom untuk menentukan perbedaan ratarata adalah pada kolom equal variances assumed. Berdasarkan Tabel 5 di atas, diketahui jika nilai Sig. (2-tailed) sebesar 0,297 lebih besar dari sig $\alpha$ 0,05 putusan yang dapat disimpulkan adalah $\mathrm{H}_{2}$ ditolak. Hasil uji menyatakan tidak terdapat perbedaan kinerja pasar perusahaan keuangan dan non keuangan yang mengungkapkan beban CSR.

Pasar saham yang saat ini terjadi di Indonesia adalah pasar saham berkembang. Investor pada pasar saham yang masih berkembang umumnya menyukai investasi jangka pendek dan lebih tertarik memperoleh return tinggi, daripada fokus pada keberlangsungan perusahaan dalam jangka panjang dengan melakukan transkasi jual beli saham secara harian. Perusahaan yang diminati oleh investor adalah perusahaan yang akan menjamin tingkat return tinggi bagi 
investor daripada perusahaan yang melakukan pemborosan sumber daya sehingga berdampak pada besarnya return yang diterima investor (Ongkowijoyo dan Juniarti, 2015).

Investor di pasar saham yang berkembang ketika melakukan investasi jangka pendek cenderung merespon negatif pengungkapan beban CSR, hal ini dikarenakan beban operasi perusahaan yang muncul disebabkan oleh beban kegiatan CSR berdampak pada berkurangnya besaran laba perusahaan dan berimbas pada jumlah return yang didapatkan investor. Konar dan Cohen (2001) dalam Anderson-Weir (2010) mengungkapkan kegiatan CSR yang dilakukan perusahaan mengakibatkan peningkatan beban operasi sehingga menyebabkan penurunan profitabilitas dan berimbas pada kinerja pasar perusahaan. Sahoo (2011) menyebutkan bahwa stockholders hanya mempunyai satu keuntungan yaitu adalah dengan memaksimalkan keuntungan finansial yang diperoleh. Jika manajer terlibat pada aksi pengungkapan CSR dan tindakan bertanggung jawab secara sosial yang mengakibatkan pengurangan return shareholders, maka tindakan tersebut bukanlah CSR melainkan bisnis yang tidak bertanggung jawab secara sosial. Keadaan tersebut akan menempatkan perusahaan pada kondisi yang kurang menguntungkan dibandingkan dengan perusahaan yang memiliki beban CSR rendah. Nilai dari pemegang sahampun akan dirusak oleh adanya pembiayaan tersebut (Wibowo dan Faradiza, 2014).

Pengujian pada hipotesis $\mathrm{H}_{1 \mathrm{~b}}$ memberikan hasil bahwa pengungkapan beban CSR tidak berpengaruh signifikan pada kinerja pasar perusahaan keuangan. Temuan ini menandakan bahwa beban CSR tidak berpengaruh signifikan pada 
kinerja pasar perusahaan keuangan di BEI. Investor di pasar saham Indonesia, dalam hal ini tidak menggunakan informasi mengenai pengungkapan beban CSR pada perusahaan keuangan dalam melakukan pengambilan keputusan investasi. Crisostomo et al. (2011) mengungkapkan pada pasar saham yang berkembang kegiatan CSR tidak mempengaruhi kinerja pasar perusahaan, karena tekanan dari stakeholders pada perusahaan untuk melakukan kegiatan CSR masih minim, terutama untuk perusahaan keuangan karena bisnisnya tidak berdampak langung pada lingkungan dan sosial masyarakat.

Hasil pengujian untuk hipotesis $\mathrm{H}_{1 \mathrm{c}}$ menunjukkan pengungkapan beban CSR yang dilakukan perusahaan non keuangan berpengaruh negatif signifikan pada kinerja pasar perusahaan. Ini menandakan bahwa pasar tidak percaya pada pengungkapan beban CSR yang dilakukan perusahaan non keuangan akan memberi nilai tambah pada perusahaan dan bahkan akan menempatkan tekanan negatif pada nilai perusahaan dan berdampak pada kinerja pasar perusahaan. Wawancara yang dilakukan Setiawan dan Tjiang (2011) kepada beberapa investor dan analisis saham mengatakan bahwa pengungkapan beban CSR tidak akan memiliki efek pada keputusan investasi terutama pada investasi jangka pendek. Hal yang paling penting yang harus dipertimbangkan adalah kinerja keuangan perusahaan dan price earning ratio. Selain itu, pengungkapan CSR yang dilakukan oleh perusahaan biasanya hanya digunakan sebagai bagian dari iklan dan promosi perusahaan semata (Octavia dan Hermi, 2014).

Nilai $\mathrm{R}^{2}$ dari ketiga hasil pengujian tergolong kecil dan tidak mendekati angka 10 persen, hal ini menandakan bahwa variabilitas kinerja pasar perusahaan 
di BEI yang dapat dijelaskan oleh pengungkapan beban CSR masih rendah. Pengungkapan beban CSR bukanlah penentu utama bagi investor dalam melakukan pengambilan keputusan investasi. Terdapat alasan lain yang dilihat oleh investor ketika melakukan pengambilan keputusan investasi beberapa diantaranya seperti, pembagian deviden, kinerja keuangan perusahaan, price earning ratio dan yang lainnya. Hal ini mengakibatkan hasil dari pengujian tidak mendukung ketiga hipotesis yang diberikan.

Hasil penelitian untuk hipotesis $\mathrm{H}_{1 \mathrm{a}}$ dan $\mathrm{H}_{1 \mathrm{c}}$ ini selaras dengan penelitian Anderson-Weir (2010), Brammer et al. (2005) dan Jones et al. (2007). Penelitianpenelitian tersebut memberikan hasil dimana pengungkapan CSR berpengaruh negatif signifikan pada kinerja pasar perusahaan yang diukur dengan menggunakan CAR. Selain itu ada juga penelitian dari Alexander dan Buchloz (1978) yang mendukung hasil hipotesis $\mathrm{H}_{1 \mathrm{~b}}$ dimana tidak ditemukannya hubungan antara pengungkapan CSR dengan stock market performance.

Hasil pengujian untuk hipotesis $\mathrm{H}_{2}$ menunjukkan tidak terdapat perbedaan kinerja pasar perusahaan keuangan dan non keuangan yang mengungkapkan beban CSR. Pengungkapan beban CSR yang dilakukan perusahaan keuangan ataupun non keuangan tidak terdapat perbedaan, hasil ini sama dengan penelitian Adeneye dan Ahmed (2015) yang mengatakan meskipun jenis perusahaan dapat meningkatkan CSR perusahaan tetapi hubungan tersebut tidak mempengaruhi perbedaan dari kinerja perusahaan. Selain itu, investor cenderung kurang fokus pada jenis perusahaan yang memberikan informasi mengenai beban CSR dan lebih menyukai informasi mengenai kinerja keuangan perusahaan. Perilaku 
tersebut mengakibatkan investor tidak memberikan respon yang berbeda apakah perusahaan keuangan dan non keuangan melakukan pengungkapan beban CSR secara rinci atau tidak. Selama perusahaan tersebut laba dan mampu memberikan return yang tinggi, maka investor akan memberikan proporsi dan perhatian yang lebih pada perusahaan tersebut. Ini akibat dari pasar saham di Indonesia yang masih berkembang dan sensitivitas investor akan kegiatan CSR serta keberlangsungan usaha dalam jangka panjang belum tinggi (Putranto dan Kewal, 2014).

Alasan lain mengapa kinerja pasar perusahaan keuangan dan non keuangan yang mengungkapkan beban CSR tidak terdapat perbedaan adalah dikarenakan pada sampel perusahaan non keuangan jenis industri yang tergolong dalam perusahaan ini terdiri dari berbagai macam sektor diantaranya pertambangan, pertanian, properti, transportasi, manufaktur, otomotif, jasa, telekomunikasi dan konsumsi. Kegiatan bisnis perusahaan yang beragam dan lingkup operasi perusahaan yang berbeda mengakibatkan terjadinya bias industri (Nabhan, 2001).

\section{SIMPULAN DAN SARAN}

Hasil penelitian ini mendukung teori signalling yang mengungkapkan jika sinyal yang diungkapkan oleh perusahaan berguna dan bernilai tambah maka investor dan calon investor akan bereaksi di pasar modal. Selain itu diketahui bahwa pengungkapan beban CSR pada kinerja pasar perusahaan di BEI tahun 2011-2015 adalah berpengaruh negatif signifikan. Pada perusahaan keuangan pengungkapan beban CSR pada kinerja pasar tidak berpengaruh signifikan dan 
pada perusahaan non keuangan diketahui berpengaruh negatif signifikan. Lebih lanjut lagi diketahui tidak terdapat perbedaan kinerja pasar perusahaan antara perusahaan keuangan dan non keuangan yang mengungkapkan beban CSR tersebut.

Terdapat beberapa saran serta keterbatasan pada penelitian ini mengakibatkan masih perlunya pengembangan lebih lanjut dan perbaikan guna memperoleh hasil penelitian yang lebih baik pada penelitian-penelitian selanjutnya. Saran yang sekiranya relevan untuk dirumuskan berdasarkan hasil pembahasan dan simpulan di atas adalah investor kedepannya diharapkan lebih menyadari akan pentingnya informasi pengungkapan beban CSR dan menggunakan informasi tersebut sebagai salah satu bahan pertimbangan dalam melakukan investasi. Perusahaan yang melakukan kegiatan CSR menandakan bahwa perusahaan tersebut mampu melakukan pembiayaan dan memperhatikan tanggung jawab sosial terhadap lingkungan dan masyarakat disekitar perusahaan.

Bagi peneliti, selanjutnya dapat menggunakan penelitian ini sebagai salah satu referensi untuk digunakan pada penelitian serupa dengan menggolongkan perusahaan berdasarkan sektor industrinya masing-masing. Selain itu peneliti kedepannya dapat melakukan pengujian pada perusahaan keuangan dan perusahaan yang berhubungan dengan sumber daya alam dengan perusahaan yang tidak termasuk kedua jenis industri tersebut seperti; travel, jasa dan yang lainnya. Dapat juga melakukan analisis mengenai perbedaan kinerja pasar perusahaan yang menggunakan laba ditahan sebagai pembiayaan kegiatan CSR dengan perusahaan yang menggunakan laba berjalan sebagai pembiayaan kegiatan CSR. 


\section{REFERENSI}

Adeneye, Yusuf Babatunde dan Maryam Ahmed. 2015. Corporate Social Responsibility and Company Performance. Journal of Business Studies Quarterly (1)7 pp:151-166.

Ahmad, Nik Nazli bt Nik, Maliah bt Sulaiman dan Dodik Siswantoro. 2003. Corporate Social Responsibility Disclosure in Malaysia: An Analysis of Annual Reports of KLSE Listed Companies. Journal of Economics and Management (1)11 pp:1-37.

Akanbi, Paul Ayobami dan Onyema Eugene Ofoegbu. 2012. Impact of Corporate Social Responsibility on Bank Performance in Nigeria. Journal of USChina Public Administration (4)9 pp:374-383.

Alexander, Gordon J. dan Rogene A. Buchholz. 1978. Corporate Social Responsibility and Stock Market Performance. Academy of Management Journal (3)21 pp:479-486.

Alkababji, Majdi Wael. 2014. Voluntary Disclosure on Corporate Social Responsibility: A Study On The Annual Reports Of Palestinian Corporations. European Journal of Accounting Auditing and Finance Research (4)2 pp:59-82.

Anderson-Weir, Charles H. 2010. How Does the Stock Market React to Corporate Enviromental News?. Undergraduate Economic Review (1)6 pp:1-29.

Anggraini, Fr. Reni. Retno. 2006. Pengungkapan Informasi Sosial dan FaktorFaktor yang Mempengaru,ihi Pengungkapan Informasi Sosial dalam Laporan Keuangan Tahunan. Simposium Nasional Akuntansi IX Padang.

Arya, Bindu dan Gaiyan Zhang. 2009. Institusional Reforms and Investor Reactions to CSR Announcements: Evidence from an Emerging Economy. Journal of Management Studies (7)46 pp:1089-1112.

Babalola, Yisau Abiodun. 2012. The Impact of Corporate Social Responsibility on Firms Profitability in Nigeria. European Journal of Economics, Finance and Administrative Sciences. Issues 45 pp:39-50. Available at http://www.kau.edu.sa/. Diakses 21 Februari 2016.

Brammer, Stephen, Chris Brooks dan Stephen Pavelin. 2005. Corporate Social Performance and Stock Return: UK Evidence from Disaggregate. Financial Management (3)35 pp:97-116. 
Budiman, Adrian dan Juniarti. 2015. Pengaruh Corporate Social Responsibility Terhadap Respon Investor Dalam Sektor Perdagangan, Jasa dan Investasi. Business Accounting Review (2)3 hal:41-50.

Carrol, Archie B. dan Kareem M. Shabana. 2011. The Business Case for Corporate Social Responsibility. The Conference Board, Canada. Available from: www.conference-board.org. Diakses 28 Februari 2016.

Cecilia, Syahrul Rambe dan M. Zainul Bahri Torong. 2015. Analisis Pengaruh Corporate Social Responsibility, Profitabilitas dan Ukuran Perusahaan Terhadap Nilai Perusahaan pada Perusahaan Perkebunan yang Go Public di Indonesia, Malaysia, dan Singapura. Simposium Nasional Akuntansi 18 Medan.

Cheng, Megawati dan Yulius Jogi Christiawan. 2011. Pengaruh Pengungkapan Corporate Social Responsibility Terhadap Abnormal Return. Jurnal Akuntansi dan Keuangan, (13)1 hal:24-36.

Chetty, Sukanya, Rebekah Naidoo dan Yudhvir Seetharam. 2014. The Impact of Corporate Social Responsibility on Firms' Financial Performance in South Africa. Contemporary Economics (2)9 pp:193-214.

Crisostomo, Vicente Lima, Fatima de Souza Freire dan Felipe Cortes de Vasconcellos. 2014. Corporate Social Responsibility, Firm Value and Financial Performance in Brazil. Social Responsibility Journal (2)7 pp:295-309.

Crowther, David dan Guler Aras. 2008. Corporate Social Responsibility. Available from: www.BookBooN.com. Diakses 21 Februari 2016.

Edmans, Alex, Lucius Li dan Chendi Zhang. 2014. Employee Satisfaction, Labor Market Flexibility, and Stock Returns Around The World. NBER Working Paper No. 20300. Available from: papers.ssrn.com. Diakses 27 Februari 2016.

Epstein, Marc J. dan Martin Freedman. 1994. Social Disclosure and The Individual Investor. Accounting, Auditing and Accountability Journal (4)7 pp:94-109.

Fitriani, Anis. 2013. Pengaruh Kinerja Lingkungan dan Biaya Lingkungan Terhadap Kinerja Keuangan pada BUMN. Jurnal Ilmu Manajemen (1)1 hal:137-148. 
Freeman, R. Edward. 1994. Stakeholder Theory of The Modern Corporation. General Issues in Business Ethics pp:38-48. Available from: businessethics.qwriting.qc.cuny.edu/files/2012/01/Freeman.pdf. Diakses 28 Februari 2016.

Hadi, Nor. 2011. Interaksi Tanggung Jawab Sosial, Kinerja Sosial, Kinerja Keuangan dan Luas Pengungkapan Sosial. Maksimum (2)1 hal:59-67.

Hall, Pamela L. dan Robin Rieck. 1998. The Effect of Positive Corporate Social Actions on Shareholder Wealth. Journal of Financial and Strategic Decisions (2)11 pp:83-89.

Hendarti, Henny. 2006. Peranan Biaya Sosial dalam Meningkatkan Kinerja Sosial dan Keuangan Perusahaan High dan Low Profile. Journal The Winners (2)7 hal:128-143.

Hermawan, Sigit dan Afiyah Nurul Maf'ulah. 2014. Pengaruh Kinerja Keuangan Terhadap Nilai Perusahaan Dengan Pengungkapan Corporate Social Responsibility Sebagai Variabel Pemoderasi. Jurnal Dinamika Akuntansi (2)6 hal:103-118.

Hohnen, Paul. 2007. Corporate Social Responsibility, An Implementation Guide for Business. International Institute for Sustainable Development. Available from: http://www.iisd.org/pdf/2007/csr_guide.pdf. Diakses 21 Februari 2016.

Ilmi, Sri Fadilah dan Diamonalisa S. 2015. Pengaruh Pengungkapan Corporate Social Responsibility terhadap Keputusan Investasi. Prosiding Penelitian Sivitas Akademika Unisba (Sosial dan Humaniora) hal:67-74.

International Standard 26000. 2010. Guidance on Social Responsibility. Available from: $\quad$ http://www.uobaghdad.edu.iq/uploads/pics13/qaa/iso26000.pdf. Diakses 28 Februari 2016.

Jogiyanto, Hartono. 2014. Teori Portofolio dan Analisis Investasi: Edisi Kesembilan. Yogyakarta: BPFE-Yogyakarta.

Jones, Stewart, Geoff Frost, Janice Loftus dan Sandra Van Der Laan. 2007. An Empirical Examination of The Market Returns and Financial Performance of Entities Engaged in Sustainability Reporting. Australian Accounting Review (17)1 pp:78-87.

Kastutisari, Savitri dan Nurul Hasana Uswati Dewi. 2014. Pengaruh Pengungkapan Corporate Social Responsibility (CSR) Terhadap Abnormal 
Return. E-Jurnal Ekonomi dan Bisnis Universitas Udayana (2)3 hal:102121.

Lean, Hooi Hooi dan Yuan Chang. 2011. Corporate Social Responsibility and Stock Returns: Stochastic Dominance Approach. African Journal of Business Management (4)5 pp:1277-1285.

Lentner, Csaba, Krisztina Szegedi, Tibor Tatay. 2015. Corporate Social Responsibility in the Banking Sector. Public Finance Quarterly (1) pp:95103

Luhgiatno. 2007. Akuntansi Sosial Bentuk Kepedulian Perusahaan Terhadap Lingkungan. Fokus Ekonomi (2)2 hal:1-16.

Lyon, Thomas P. dan John W. Maxwell. 2008. Corporate Social Responsibility and the Environment: A Theoretical Perspective. Review of Enviromental Economics and Policy (0)1 pp:1-22.

Mardiandari, Putri dan Sri Rustiyaningsih. 2013. Tanggung Jawab Sosial dan Kinerja Keuangan pada Perusahaan Manufaktur Go Publik di Bursa Efek Indonesia. Jurnal Riset Manajemen dan Akuntansi (1)1 hal:70-80.

Mawandira, Sasi Ika, Stevanus Hadi Darmadji dan Aurelia Carina Sutanto. Pengaruh Karakteristik Perusahaan Terhadap Pengungkapan Corporate Social Responsibility (CSR) Pada Sektor Non Keuangan dan Non BUMN yang Terdaftar Di BEI Tahun 2010, 2011, dan 2012. Jurnal Ilmiah Mahasiswa Universitas Surabaya (2)3 hal:1-20.

Mwamburi, Stacey Philomena. 2015. The Effect Of Corporate Social Responsibility Announcement On Stock Returns at The Nairobi Securities Exchange. A Research Project Submitted in Partial Fullfillment of The Requirements for The Award of The Degree of Master of Business Administration. University of Nairobi.

McGuire, Jean B. 1988. Corporate Social Responsibility and Firm Financial Performance. Academy of Management Journal (4)31 pp:854-872.

McWilliams, Abagail, Donald S. Siegal dan Patrick M. Wright. 2005. Corporate Social Responsibility: Strategic Implications. Working Papers in Economics. Available from: http://www.economics.rpi.edu/workingpapers/rpi0506.pdf. Diakses 21 Februari 2016. 
Murni, Sri. 2001. Akuntansi Sosial: Suatu Tinjauan Mengenai Pengakuan, Pengukuran dan Pelaporan Externalities dalam Laporan Keuangan. Jurnal Akuntansi dan Investasi (1)2 hal:27-44.

Nabhan, Faqih. 2001. "Pengaruh Leverage Keuangan dan Sektor Industri Terhadap Return Saham, Pertumbuhan Penjualan dan Laba Operasi Perusahaan-Perusahaan Go Public yang Terdaftar di Bursa Efek Jakarta" (tesis). Semarang: Universitas Diponegoro.

Nurdin, Emilia dan M. Fani Cahyandito. 2006. Pengungkapan Tema-Tema Sosial dan Lingkungan Dalam Laporan Tahunan Perusahaan Terhadap Reaksi Investor. Pustaka Ilmiah Padjajaran. Available from: pustaka.unpad.ac.id. Diakses 1 Juni 2016.

Oktavia, Monica dan Juniarti. 2015. Pengaruh Corporate Social Responsibility Terhadap Respon Investor Dalam Sektor Pertanian. Business Accounting Review (2)3 hal:11-20.

Oktavia, Helen dan Hermi. 2014. Pengaruh Tanggung Jawab Sosial Perusahaan Terhadap Kinerja Perusahaan (Studi Empiris pada Perusahaan Manufaktur yang Tercatat di Bursa Efek Indonesia Pada Tahun 2010 dan 2011. Jurnal Akuntansi (1)1 Hal:41-59

Ongkowijoyo, Elsa dan Juniarti. 2015. Pengaruh Corporate Social Responsibility Terhadap Respon Investor Dalam Sektor Infrastruktur, Utilitas, dan Transportasi Di Indonesia. Business Accounting Review (3)1 pp:233-244.

Owen, Crystal L. dan Robert F. Scherer. 1993. Social Responsibility and Market Share. Review of Business (1)15 pp:11-16.

Peraturan Menteri Negara Badan Usaha Milik Negara Nomor Per-05/MBU/2007 Tentang Program Kemitraan Badan Usaha Milik Negara Dengan Usaha Kecil dan Program Bina Lingkungan. Available from bumn.go.id. Diakses 28Februari 2016.

Prayosho, Indra Sari dan Hari Hananto. 2013. Pengaruh Sustainability Reporting Terhadap Abnormal Return Saham Pada Badan Usaha Sektor Pertambangan Yang Terdaftar Di BEI Periode 2010-2012. Jurnal Ilmiah Mahasiswa Universitas Surabaya (2)2 hal:1-12.

Putranto, Yohanes Andri dan Suramaya Suci Kewal. 2014. Pengaruh Corporate Social Responsibility Berbasiskan Karakteristik Social Bank Terhadap Kinerja Perusahaan Perbankan Di Bursa Efek Indonesia. Jurnal Akuntansi (3)18 hal:479-490. 
Roden, Peyton Foster dan Filiberto Enrique Valdes Medina. 2011. An Analysis Of Corporate Social Responsibility: The Mexico Evidence. Journal of Financial and Economic Practice (2)11 pp:64-76.

Sahoo, Chandrakanta. 2011. Corporate Social Responsibility: Issues and Controversies. European Journal of Business and Management (2)3 hal:15.

Sari, Eka Nurmala dan Elizar Sinambela. 2008. Pengaruh Pengungkapan Tanggung Jawab Sosial Perusahaan Terhadap Kinerja Keuangan Perusahaan. Jurnal Riset Akuntansi dan Bisnis (2)8 hal:1-21.

Septiana, Rika Amelia dan Emrinaldi Nur DP. 2012. Pengaruh Implementasi Corporate Social Responsibility Terhadap Profitabilitas Perusahaan. Pekbis Jurnal (2)4 hal:71-84.

Setiawan, Evelyn dan Gupita Janet Tjiang. 2011. Corporate Social Responsibility, Financial Performance, and Market Performance: Evidence from Indonesian Consumer Goods Industry. 6th Asian Business Research Conference.

Spence, Michael. 1973. Job Market Signaling. The Quarterly Journal of Economics (3)87 pp:355-374.

Suchman, Mark C. 1995. Managing Legitimacy: Startegic and Institusional Approaches. Academy of Management The Academy of Management Review (3)20 pp:571-610.

Sueb, Memed. 2001. Pengaruh Biaya Sosial Terhadap Kinerja Sosial, Keuangan Perusahaan Terbuka Di Indonesia. Simposium Nasional Akuntansi IV Bandung.

Sugiyono. 2010. Metode Penelitian Kuantitatif Kualitatif dan R\&D, Alfabeta, Bandung.

Sukanto, Eman. 2012. Pengaruh Pengungkapan Corporate Social Responsibility Terhadap Stock Return Pada Perusahaan Yang Berkaitan Dengan Lingkungan Yang Listing Di Bursa Efek Indonesia Tahun 2010-2011. Fokus Ekonomi (2)7 hal:45-57.

Titisari, Kartika Hendra, Eko Suwardi dan Doddy Setiawan. 2010. Corporate Social Responsibility (CSR) dan Kinerja Perusahaan. Simposium Nasional Akuntansi XIII Purwokerto 2010. 
Tjiasmanto, Vennetia Mutiara dan Juniarti. 2015. Pengaruh Pengungkapan Corporate Social Responsibility Terhadap Respon Investor Dalam Sektor Aneka Industri. Business Accounting Review (1)3 hal:67-77.

Tregidga, Helen, Markus Milne dan Kate Kearins. 2006. Organisational Legitimacy And Social And Environmental Reporting Research: The Potential of Disclosure Analysis. The $5^{\text {th }}$ Australasian Conference on Social and Enviromental Accounting Research Wellington 2006.

Undang-Undang Republik Indonesia Nomor 40 Tahun 2007 Tentang Perseroan Terbatas. LN No. 106 Tahun 2007, TLN No. 4756.

Vijaya, Diota Prameswari. 2012. Pengaruh Pengungkapan Tanggung Jawab Sosial Perusahaan Terhadap Aktivitas Volume Perdagangan dan Harga Saham. Jurnal Ilmiah Akuntansi dan Humanika (2) 1 hal:1-24.

Wang, Yungchih George. 2011. Corporate Social Responsibility and Stock Performance, Evidence From Taiwan. Scientific Research (2) pp:788-799.

Weshah, Sulaiman R., Ahmad A. Dahiyat, Mohammed R. Abu Awwad dan Emad S. Hajjat. 2012. The Impact of Adopting Corporate Social Responsibility on Corporate Financial Performance: Evidence from Jordanian Banks. Interdisciplinary Journal of Contemporary Research in Business (4)5 pp:34-44.

Wibowo, Imam dan Sekar Akrom Faradiza. 2014. Dampak Pengungkapan Sustainability Report Terhadap Kinerja Keuangan dan Pasar Perusahaan. Simposium Nasional Akuntansi 17 Mataram Lombok.

World Business Council for Sustainable Development (WBCSD). 1999. Corporate Social Responsibility. Meeting Changing Expectations Geneva. Available from: www.wbcsd.org. Diakses 28 Februari 2016.

Yamagami, Tatsundo dan Katsuhiko Kokobu. 1991. A Note on Corporate Social Disclosure in Japan. Accounting, Auditing \& Accountability Journal (4)4 pp:32-39.

Yani, Widya dan Wahidahwati. 2013. Pengaruh Pengungkapan Corporate Social Responsibility Terhadap Kinerja Perusahaan. Jurnal Ilmu \& Riset Akuntansi (2)2 hal:1-19. 